\title{
Definition of a global boundary stratotype for the Darriwilian Stage of the Ordovician System
}

\author{
I Department of Geology, the State University of New York at Buffalo, Buffalo, NY 14260-3050, USA \\ 2 Nanjing Institute of Geology and Paleontology, 39 Beijing East Road, Nanjing 210008. China \\ 3 Department of Geological Sciences, Ohio State Universitv, Columbus, OH 43210-1397. USA \\ 4 Centre for Ecostratigraphy and Palaeobiology, Macquarie University, NSW 2109. Australia. \\ 5 Department of Geological Sciences at California State University, Long Beach, California 90840, USA
}

The International Commission on Stratigraphic Nomen-
clature and the IUGS Executive Committee have recently approved selection of a global stratotype section and point defining the base of the second stage of the Middle Ordovician Series. This stage is named the Darriwilian Stage after the Australian regional stage of the same name, with which it shares identical definition and scope. The base of the Darriwilian Stage is fixed at the base of the Undulograptus austrodentatus Biozone in a section through the Ningkuo Shale exposed at Huangnitang, Changshan County, Zhejiang Province, southeast China. This boundary is defined by the first appearance datum of the $\mathrm{U}$. austrodentatus within a densely sampled succession of graptolite first occurrences that facilitate precise global correlation of this boundary. Conodont species are also present within this section and indicate that the base of the Darriwilian is likely to lie within the lower part of the Microzarkodina parva Biozone of the North Atlantic conodont zonal succession. Correlation of this boundary with well studied successions elsewhere indicates that it is coeval with a level in the mid Whiterockian in North America, and in the lower Fennian Stage of the upper Arenig of Wales. The base of the Darriwilian is about $467.5 \pm 3 \mathrm{Ma}$.

\section{Introduction}

Advances in our knowledge of the Earth s history. including development of an increasingly refined geological time scale, have led to the posing of questions in many areas of geological research that require yet further increases in the precision and reliability of this time scale. To address this need in the Ordovician, the IUGS/ICS Subcommission on Ordovician Stratigraphy since 1989 has been engaged in an active program aimed at identifying those biological event horizons that exhibit the greatest potential for chronostratigraphic subdivision of the Ordovician System for world-wide use. In particular, this effort has focused on especially widely recognizable biozones within the pelagie graptolite and conodont faunas. The high degree of biogeographic differentiation which characterizes Ordovician biotas has made development of a precise, unified global standard a slow and difficult process. In most regions of the world, provincially based, regional subdivisions are still actively used. The Ordovician System was first established in the British Isles and consequently the British series, although also based on local and often endemic biotas, have been widely employed as a lingua franca for international correlation within the Ordovician. Given these facts, adoption of the new global subdivisions and nomenclature will be a gradual process. Nevertheless, several important first steps have been accomplished, including the first, formally ratified proposal for a global Ordovician stage.

Early in 1996, by a $90 \%$ majority, the Titular members of the Ordovician Subcommission voted in favor of a division of the system into three series named the Lower, Middle, and Upper Ordovician. This provides the basis for the next step; that is, to adopt a simple six-fold global stage level division in which each series is divided into two stages. Most of the stages and series have yet to be formally defined or named, but potential levels for their bases have been identified with particular conodont or graptolite biozones with potential for long range correlation. The general framework of these global stages and series of the Ordovician System has now emerged (Figure 1). It is within this context that the Darriwilian GSSP has been proposed.

The task of identifying suitable levels for series and system subdivision has been conducted by means of a series of intra-Ordovician working groups. Within the interval of the Middle Ordovician (Figure 1), the Ordovician Subcommission working groups identified two biozonal levels that appeared to have potential for subdivision of the series: the base of the Didymograptus artus $(=D$. bifidus of Elles), and the Undulograptus austrodentatus biozones. The former level is coincident with the base of the British Llanvirn Series, and the second with the base of the Darriwilian Stage of Australia. The scope, rank, and correlation of the Llanvirn Series have been the subject of much discussion and disagreement (among recent papers see, for example, Fortey and others. 1990; Cooper and Lindholm, 1990; Malet, 1992; Berry, 1995). Fortey and others (1995), in an effort to address the need for a better unit in this interval, recently revised the Llanvirn Series. Although they identified a possible stratotype section for the base of the Llanvirn in Wales (see Fortey and others, 1991. p. 13), no Welsh candidate sections for a global stratotype at this level have been submitted to the Subcommission for Ordovician Stratigraphy for consideration. Members of the Artus Working Group discussed several additional sections from other regions of the world as a potential stratotype for a stadial boundary at the base of the $D$. artus Biozone, but none appear ideal and again none have been submitted formally to the Subcommission for consideration.

The Ordovician succession in Australia has a long history of biostratigraphic study. The Darriwilian Stage was erected by Hall (1899), redefined by Harris (1916, 1935), Harris and Keble (1932), and most recently by VandenBerg and Cooper (1992, p. 53) for the interval between the base of the Undulograptus castrodentatus Biozone and the Nemagraptus gracilis Biozone. Since the 1930's, the 

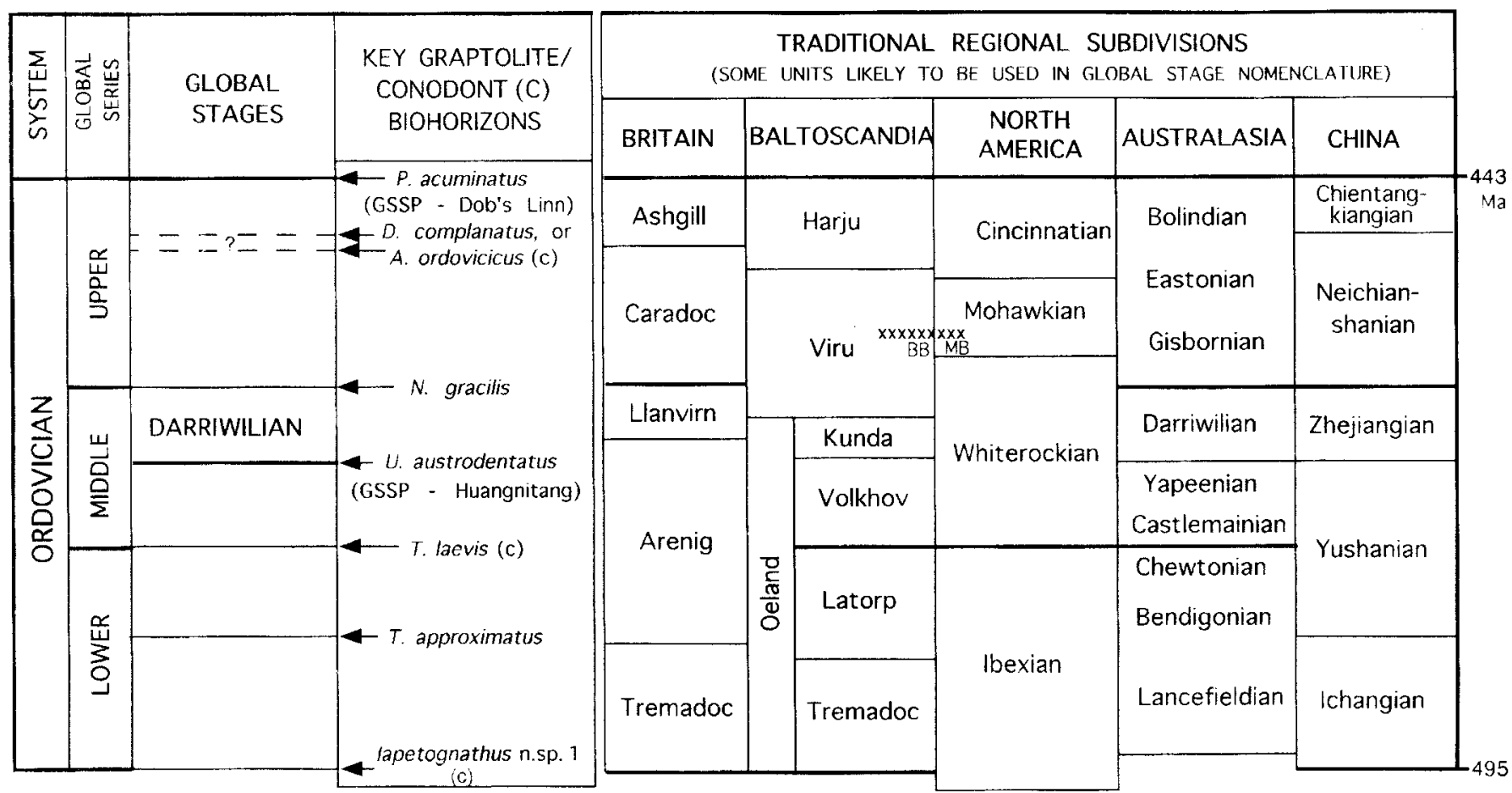

Figure I Chart illustrating stratigraphic relationships between global Ordovician Series, Stages, key faunal markers (two of which now have ratified GSSPs) and some regional subdivisions (after Webby, 1997). Volcanic ash event marker (the Big (=Kinnekulle) Bentonite, BB, and correlative Millbrig Bentonite, $M B$ ), as well as approximate radiometric dates (after Tucker \& McKerrow 1995), also shown.

graptolite zonation upon which the Darriwilian is based has been widely used as a basis for international correlation, particularly in the Pacific Province, and is readily recognizable in graptolite facies around the globe. The Darriwilian Stage spans a stratigraphic interval which is similar to but slightly larger than that of the revised Llanvirn Series of Fortey and others (1995).

Issues raised by the need to choose one or the other of the $D$. artus or U. austrodentatus levels were discussed at length during workshops held at the Sixth Incrnational Symposium on the Ordovician System in Sydney, Australia, in 1991. and at a subcommission field meeting in Nanjing in 1993, and again at the Seventh International Symposium on the Ordovician System at Las Vegas, USA, in 1995, all minuted in issues of Ordovician News, nos. 9 (1992), 11 (1994), and 13(1996). In 1992-93. in response to discussions at the Sydney meeting of the Subcommission. Chen Xu organized an international working group to investigate sections spanning the Yapeenian-Darriwilian interval in the Jiangshan-Changshan-Yushan area (JCY area) along the border between Zhejiang and Jiangxi provinces. China, and an open invitation was made for participants to join the working group (Ordovician News. no. 9. p. 20. 1992). The resulting JCY working group included specialists from China, the USA, France, Germany, and Australia. Based on this joint investigation. as well as the previous work of our Chinese colleagues, the base of the Undulegraptus anstrodentatus Biozone of the Huangnitang section in this arca has been identitied as a suitable GSSP for the Darriwilian (Chen and others 1995b; Chen and Bergström, 1995; Mitchell and Malew 1995). This section was chosen as the GSSP becaluse it represents the best available section through the interval including the base of the $U$. arstrodentatus Biozone. Five other sections in the JCY region were included in the study, and several of these come neall to rivaling the Huangnitang section in their exposure, fossil content, and continuity of succession. With this work in mind, B. D. Webby. Chair of the Ordovician Subcommission, sent an advisory questionnaire to Titular members of the Ordovician Subcommission in carly 1995 (Ordorician News. no. 13.p. 30-31). The results of this survey provided further guidance for decision-making in favor of using the base of the $U$. arstrodentatus Biozone.
The name Darriwilian (Hall. 1899), based on the Australian regional stage, was chosen by the JCY working group because of its priority for the interval extending upwards from the base of $U$. aurtrodentatus Biozone. Furthermore, it has been agreed by a vote of the Titular members of the Subcommission (82\% in favor) in February 1996 that the overlying global stage (and series) will be defined by the base of the Nemagraptus gracilis Biozone. Thus, the conception of the global Darriwilian Stage interval, from its base to its top, conforms exactly with prior Australian regional usage.

In July of 1996 the Darriwilian GSSP proposal was overwhelmingly approved by the Titular members of the Ordovician Subcommission ( 17 votes in favor, I against. 2 abstentions. and 1 no response, for a 94\% majority). Subsequently, the Darriwilian GSSP was also approved by the ICS, and finally. ratitied by a unanimous vote of the IUGS Executive Committee at its January. 1997 meeting.

\section{Recommended global stratotype section and point}

The recommended GSSP is located along an unpaved road on the riverside near Huangnitang village. $3.5 \mathrm{~km}$ southwest of the Changshan County Town of Zhejiang Province (Figures 2. 3). The section is accessible by vehicle (in fair weathen) from the town of Erduqian. $500 \mathrm{~m}$ east of Huangnitang. A state highway connects the Changshan County Town with Hangzhou and Shanghai. Conservation and protection of the section has been assured by the Changshan County Government and the Zhejiang Provincial Government together with the Nanjing Institute of Geology and Palaeontology. Academia Sinica.

The section exposed at Huangnitang provides the thickest and most fossiliferous succession across the base of the Undulograptus austrodentatus Biozone of any that we have cxamined (Figure 4 ). The Huangnitang section comprises mainly the Ningkuo Formation. which at this locality spans the interval from Bendigonian continu- 


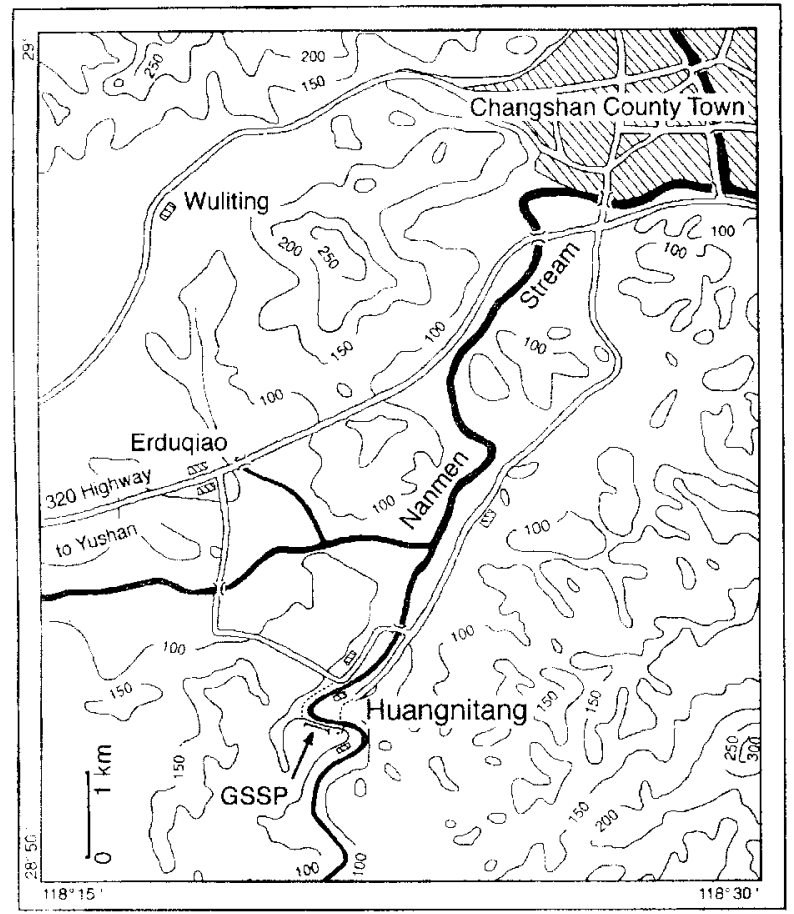

Figure 2 Map showing location of the Huangnitang-GSSP section relative to the nearby Changshan County Town.

ously to Darriwilian. The Ningkuo Formation yields abundant graptolites from the shales and conodonts from interbedded limestones. Ranges of main graptolite and conodont species in the Huangnitang section are shown in Figure 5.

The Ningkuo Formation is dominantly a well-sorted, finegrained. thinly and evenly laninated black shale (Figure 4). The base of $U$. austrodentatus Biozone in the Huangnitang section, as well as the supplementary sections in the JCY area. lics within a black shale sequence that is entirely consistent in its sediment character and reflects apparently uniform depositional conditions throughout the Yapeenian and early Darriwilian. Tabular beds of dark gray limestone interleave with the shale. Thin sections reveal that in many beds, the limestone constituents are well-sorted, fine-grained micritic intraclasts, superficial ooliths. and skeletal fragments set in calcite spar matrix. Analysis by graphic correlation based on faunal data from Huangnitang and the five supplementary sections studied in the JCY area indicates that the Huangnitang section has a consistently high sedimentation rate and no detectable stratigraphic breaks. Graptolites are common to abundant in the upper Ningkuo Formation. Above Bed AEP 178 many graptolites are pyritized and preserved in three dimensions, and from AEP 179 to about AEP 199 the rocks are essentially continuously fossiliferous.

The base of the $U$. atstrodentatts Biozone in the Huangnitang section is selected as the base of Darriwilian Stage, and is defined as the level of the first appearance datum (FAD) of the name bearer: Undulograptus austrodentatus (Figure 6). This level is coincident with the base of Bed AEP 184 of the Huangnitang section, which is $22 \mathrm{~m}$ below the top of the Ningkuo Formation (Figures 4,5 ). Graphic correlation among the six sections examined in the JCY area indicates that this appearance in the Huangnitang section corresponds to the oldest known first appearance of the species (Zhang, 1995). Thus, it is probable that the base of the $U$. atustrodentatus Biozone in this section represents the time of evolutionary origin of this key species.

The base of the Darriwilian is formally defined as the base of the $U$. alustrodentatus Biozone, however. it is important to note that identification of this boundary is a distinct process from its definjtion. The base of the Darriwilian should not be identified on the basis of the first appearance of $U$. austrodentatus alone, apart from its faunal context, but only on the basis of the species first appearance within a well controlled succession of other first-appearances. A second highly distinctive species, Arienigraptus zhejiangensis (= Pseudisograptus angel Jenkins), first occurs in bed AEP 182, $0.5 \mathrm{~m}$ below the FAD of $U$. austrodentatus. In the other JCY sections, the A. zhejiangensis FAD occupies a similar position at or just below the $U$. austrodentatus FAD. Within the precision of stratigraphic correlations in the region, the Arienigraptus zhejiangensis FAD is synchronous with the base of the $U$. austrodentatus Biozone. Thus, the appearance of $A$. thejiangensis serves as important collateral evidence of the location of the base of the Darriwilian. For this reason. we employ this species as the name-bearer of the lower subzone of the U. austrodentatus Biozone (see below).

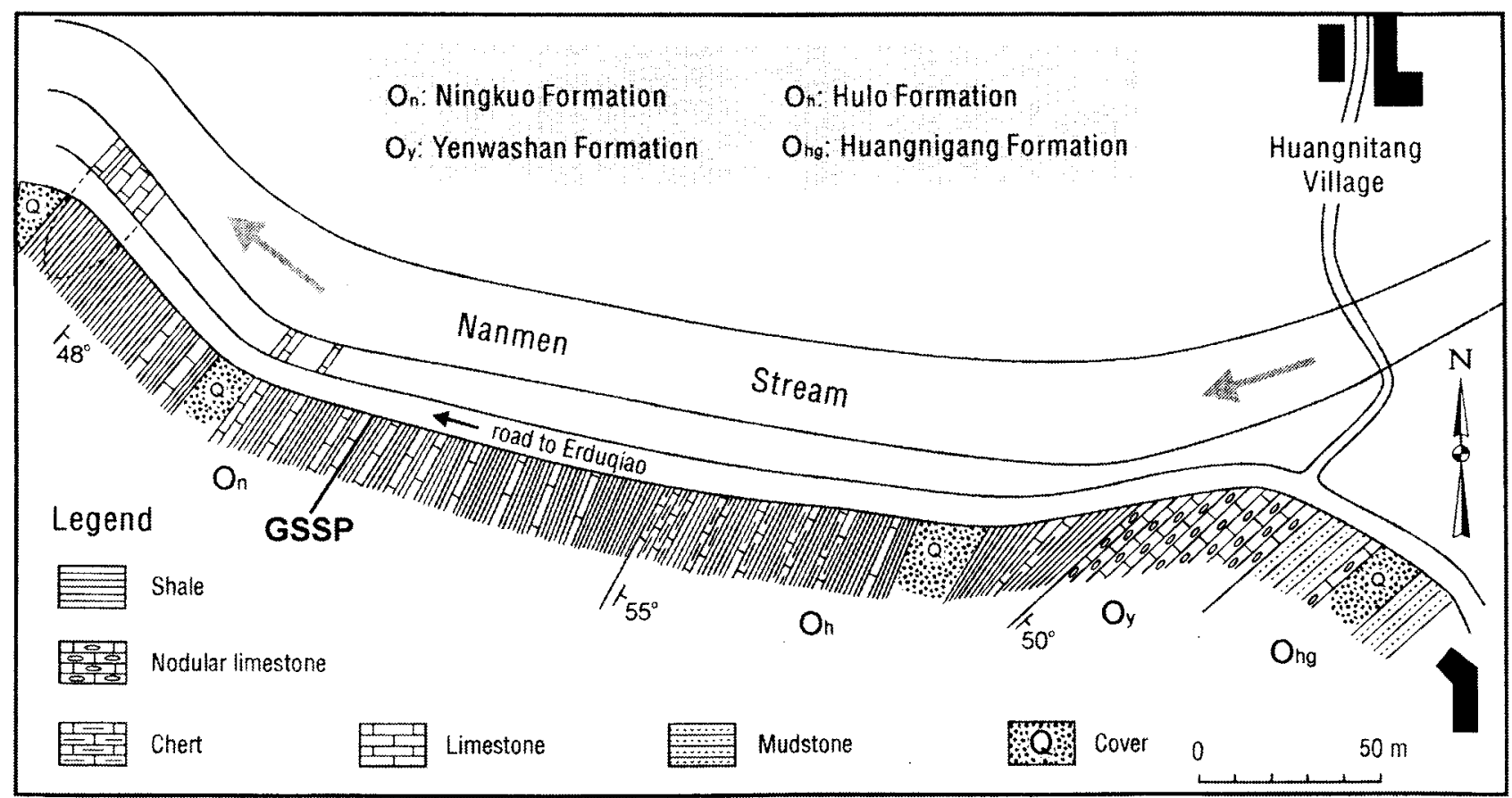

Figure 3 Geological sketch map of the Huangnitang section, Changshan, China. Rocks dip moderately to the east-south-east, and young in that direction. 


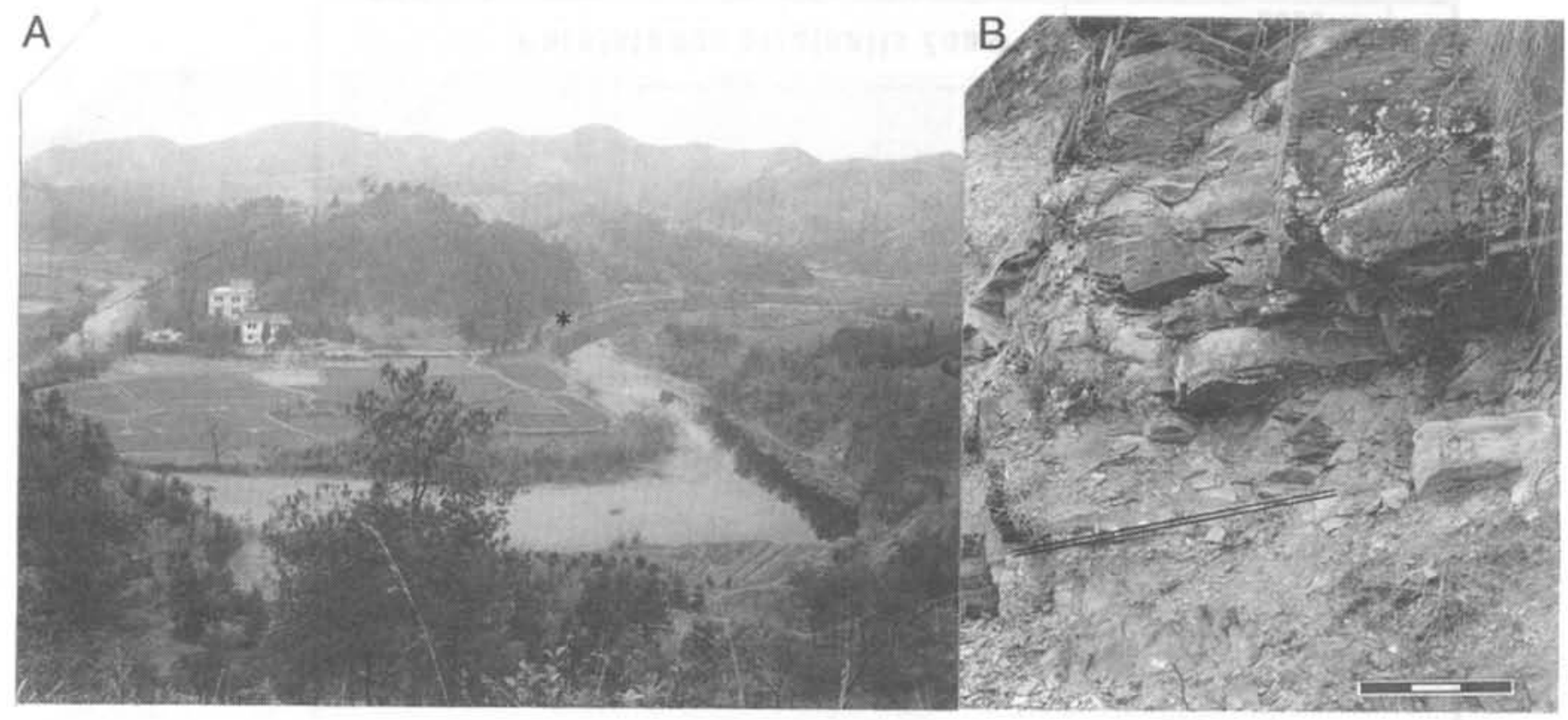

Figure 4 A. View of the Huangnitang section (looking west), and the surrounding country side. GSSP is near star along south bank of the Nanmen Stream. B. Close-up of section showing beds in the boundary interval. Base of the $\mathrm{U}$. austrodentatus Biozone and Darriwilian Stage lies at base of bed AEP 184 (indicated by double line), just above limestone bed AEP 183. Scale marked in decimeters.

\section{The graptolite record}

The presence of several short-ranging species and the pattern of graptolite species succession through the interval of the Darriwilian boundary are critical to reliable recognition of the base of the Darriwilian as well as to its precise international chronostratigraphic correlation. Several of the critical species are illustrated in Figure 6. The graptolite fauna present in the $3 \mathrm{~m}$ interval just below the base of the Darriwilian at Huangnitang is a typical Yapeenian assemblage that includes Pseudisograptus manubriatus harrisi, $P$. manubriatus koi, Exigraptus uniformis, and E. clavus (which is closely allied to Apiograptus crudus). The composite standard constructed for the JCY region (Zhang, 1995) indicates that strata in this interval in the JCY area also contain Oncograptus magnus, Arienigraptus dumosus, Isograptus victoriae maximodivergens, and $I$, victoriae divergens (see also Xiao and Chen, 1990). We refer the interval from AEP 180 to 183 to the Exigraptus clavus Biozone, the base of which is covered in this section. Shales of the mid to uppermost E. clavus Biozone (AEP 181 at Huangnitang) contain the first appearance of Cardiograptus obesus followed in bed AEP 182 by C. amplus, Undulograptus sinodentatus, and Arienigraptus zhejiangensis (Figure 5).

Based on the Huangnitang stratotype section, as well as other supplementary sections in the JCY area, we recognize two subzones, the Arienigraptus zhejiangensis (lower) and Undulograptus sinicus (upper) subzones, within the $U$. austrodentatus Biozone (Chen and others, 1995b; Mitchell and Maletz, 1995). The base of the A. zhejiangensis Subzone, like that of the zone itself, is defined by the first appearance of $U$. austrodentatus. The fauna of the $A$. zhejiangensis Subzone is very diverse and includes a rapid succession of first appearances of species of Undulograptus, Cardiograptus, and Exigraptus (Figure 5), including Undulograptus formosus, and $U$. primus. The base of the Undulograptus sinicus Subzone, is marked by the first appearance of $U$. sinicus. This level is very nearly coincident with the first appearance of Cryptograptus antennarius and Paraglossograptus tentaculatus, as well. The base of the upper subzone defines the top of the lower subzone. The last appearance of several of characteristically Yapeenian species that continue into the lower $U$. austrodentatus Biozone occurs near the base of the $U$. sinicus Subzone. These species include Pseudisograptus manubriatus, Isograptus victoriae divergens, and Oncograptus upsilon. Overlap of these species with $U$. sinicus provides a very precise control of the base of the subzone.

The Undulograptus austrodentatus Biozone is overlain in the JCY region by the Acrograptus ellesae Biozone (Xiao and Chen, 1990). Preliminary data (Zhang Yuan-dong, unpublished) indicate that species of Tylograptus, Sinograptus and other graptolites characteristic of $A$. ellesae Biozone appear in the uppermost $5.2 \mathrm{~m}$ of the Ningkuo Formation and continue into the lower part of the Hulo Formation at the Huangnitang section (Figure 5).

Accurate identification of the index species Undulograptus austrodentatus and Arienigraptus zhejiangensis (see Figure 6) is essential to recognition of the base of this biozone. In the past, considerable controversy has surrounded the issue of whether or not the appearance of "biserial graptolites" was actually synchronous around the globe (e.g., Skevington, 1963; Berry, 1968; Cooper and Lindholm, 1990; Fortey and others, 1990; Maletz. 1992). Much of the confusion arose as a consequence of application of the term "biserial" to a wide variety of species (including glossograptids) and confusion about the identification of particular species such as Didy. mograptus bifidus and $U$. austrodentatus. This problem has been solved by recent systematic work based on especially well preserved material (e.g., Cooper and Fortey, 1982; Fortey and Cooper, 1986; Mitchell, 1992, 1994; Mitchell and Maletz, 1995), although contrary interpretations continue to have advocates (e.g., Berry, 1995). Chen and others (1995a) have redescribed Undulograptus austrodentatus (Harris \& Keble) and Arienigraptus zhejiangensis Yu and Fang in detail.

\section{The conodont record}

Conodonts from limestone interbeds within the Huangnitang section (commencing with sample AEP 167) are referable to the Paroistodus originalis Biozone (Wang and Bergström, 1995). Although the fauna is of low diversity, elements are numerous and well preserved (Figure 4). They are typical of the low diversity North Atlantic 


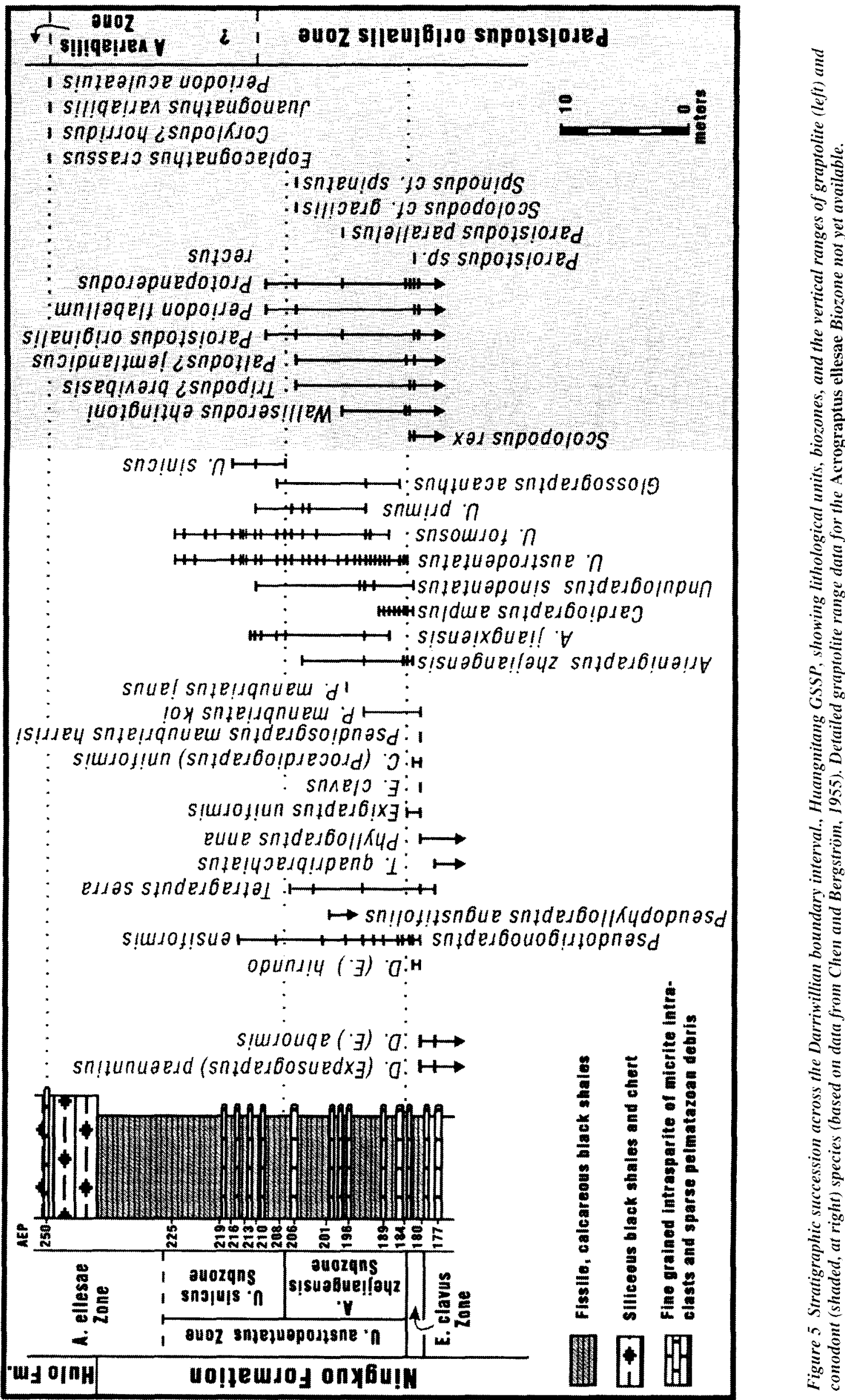



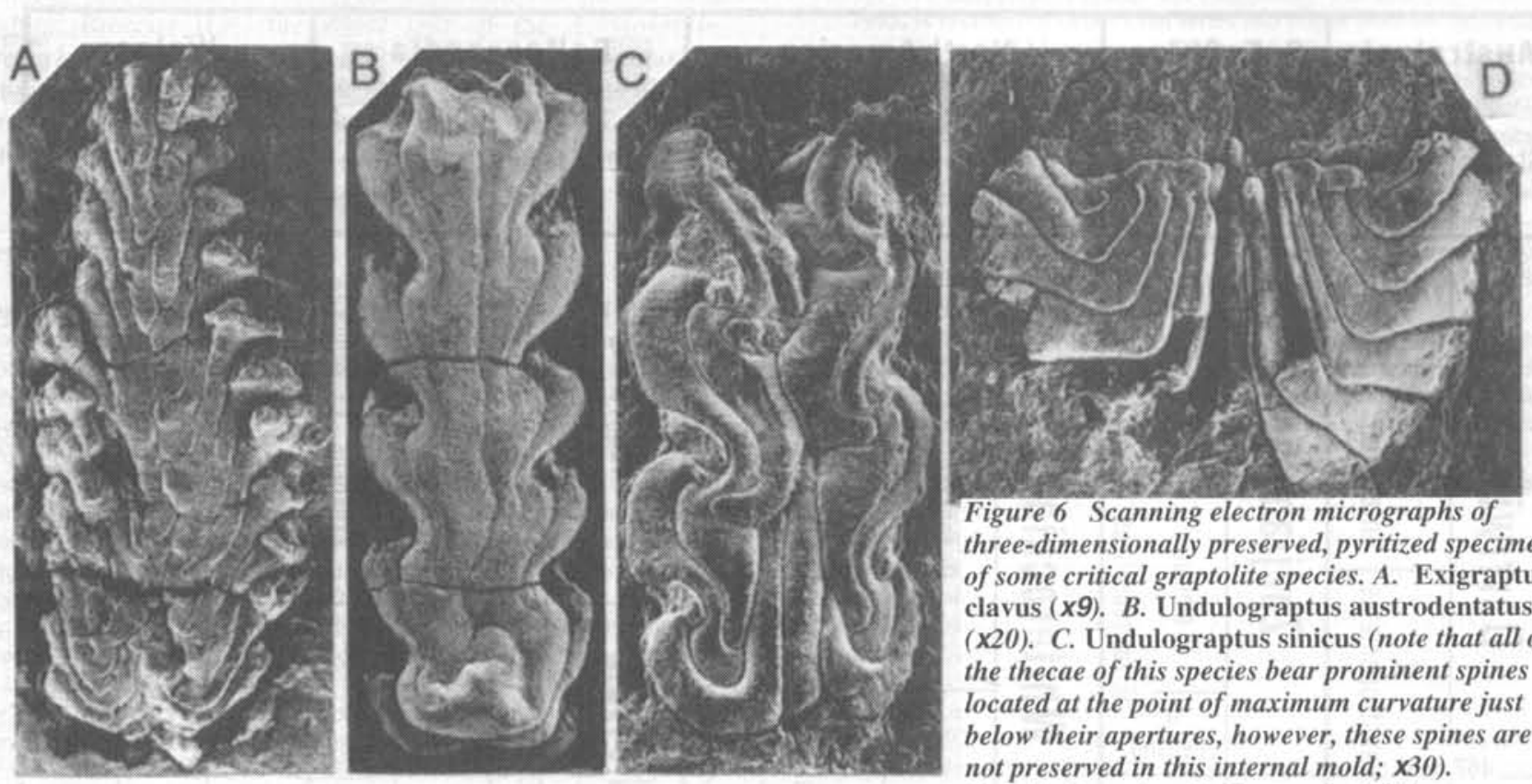

Figure 6 Scanning electron micrographs of three-dimensionally preserved, pyritized specimens of some critical graptolite species. A. Exigraptus clavus (x9). $B$. Undulograptus austrodentatus $(x 20)$. C. Undulograptus sinicus (note that all of the thecae of this species bear prominent spines located at the point of maximum curvature just below their apertures, however, these spines are not preserved in this internal mold; $\times 30)$.

$D$. Arienigraptus zhejiangensis (x 20).

Province faunas usually obtained in off-shore settings, and contain none of the shallow water endemics found in rocks of the Yangtze Platform. Based on these faunas as well as occurrences of conodonts and graptolites together in the Dawan Formation of the Yichang region, Yangtze Platform (about $700 \mathrm{~km}$ WNN of the JCY region; see Wang and Bergström, 1995), and in the Vinini Formation of central Nevada (Finney and Ethington, 1992; Mitchell, 1992), the base of the $U$. austrodentatus Biozone lies just above the base of the Microzarkodina parva Biozone in the North Atlantic conodont zonation and within the upper part of the Histiodella altifrons Biozone in the North American midcontinent conodont zonation.

Conodonts from bed AEP 250 in the Huangnitang section include Eoplacognathus crassus. In terms of graptolite zones, this bed lies within the Acrograptus ellesae Biozone. The AEP 250 conodont fauna indicates that these strata belong to the lower, but not lowermost, part of the Amorphognathus variabilis Biozone of the North Atlantic conodont zonation, consistent with an M. parva Biozone age suggested for the base of the $U$. austrodentatus Biozone.

\section{Chitinozoan and acritarch records}

Correlation between the Lower Ordovician low latitude faunas of the Pacific Province and the dominantly cool to cold water faunas of Gondwana has been a persistently difficult problem. Correlation via the trilobite faunas in Wales represents one possibility, albeit largely untested at present. Recent attempts to obtain chitinozoans from the $U$. austrodentatus boundary interval suggest another potential solution. Paris and Chen $(1995,1996)$ report discovery of chitinozoans from Huangnitang and three other sections in the JCY area. Taxa present include species of the genera Conochitina, Cyathochitina, Rhabdochitina, Tanuchitina, Laufeldochitina, Belonechitina, Desmochitina and Sagenachitina. Specimens of the first three genera are the most common in their collections. Several of these genera are known from Gondwanan locales and Sagenochitina in particular is a characteristic element of upper Arenig (Whitlandian) to lower Llanvirn strata in northern Gondwana (e.g., France, Portugal, Algeria, and Libya; see Paris, 1990).

Servais and others (1995), in an thorough revision of the distinctive acritarch Dicrodiacrodium ancoriforme, report that its first appearance lies within the latest Yapeenian $U$. sinodentatus Biozone in the Dawan Formation, China. Although not yet known from the
$\mathrm{JCY}$ area, D. ancoriforme has been previously reported widely from the Llanvirn and younger strata in Europe and northern Africa. This species is also present in late Arenig rocks within the Sárka Formation in Bohemia together with a D. bulla Biozone chitinozoan fauna (Vavrdová, 1993).

Clearly, additional work is required on these fossils and their distribution. Further research into their occurrence in the JCY and Yangtze Platform regions is underway currently. However, the available data are sufficient to indicate that chitinozoans and acritarchs may offer the opportunity to make an accurate correlation of the base of the Darriwilian with late Arenig successions of the periGondwanan realm, where $U$. austrodentatus and its associates are absent.

\section{Prospects for paleomagnetic reversal stratigraphy and radiometric age determinations}

No paleomagnetic work has yet been carried out in the Middle Ordovician sections of the JCY area. However, in view of the fact that the Conodont Color Alteration Index (CAI) is only 3-4, indicating heating of the rocks to a maximum of about $100^{\circ} \mathrm{C}-300^{\circ} \mathrm{C}$ (Wang and Bergström, 1995), there is clearly potential for successful establishment of magnetic reversal stratigraphy across the base of the Darriwilian. The only rocks in the Ningkuo Formation in the study region that are potentially useful for radiometric age determinations are two thin K-bentonite beds in the Azygograptus suecicus Biozone described by Huff and Bergström (1995) in a section at Hengtang. No radiometric age data are yet available from these beds, but in a companion paper to the present contribution, Huff and others (1997) report a U-Pb age of $464 \pm 2 \mathrm{Ma}$ from a K-bentonite located within the lower Darriwilian $U$. austrodentatus Biozone in the Precordilleran Terrane of Argentina. 


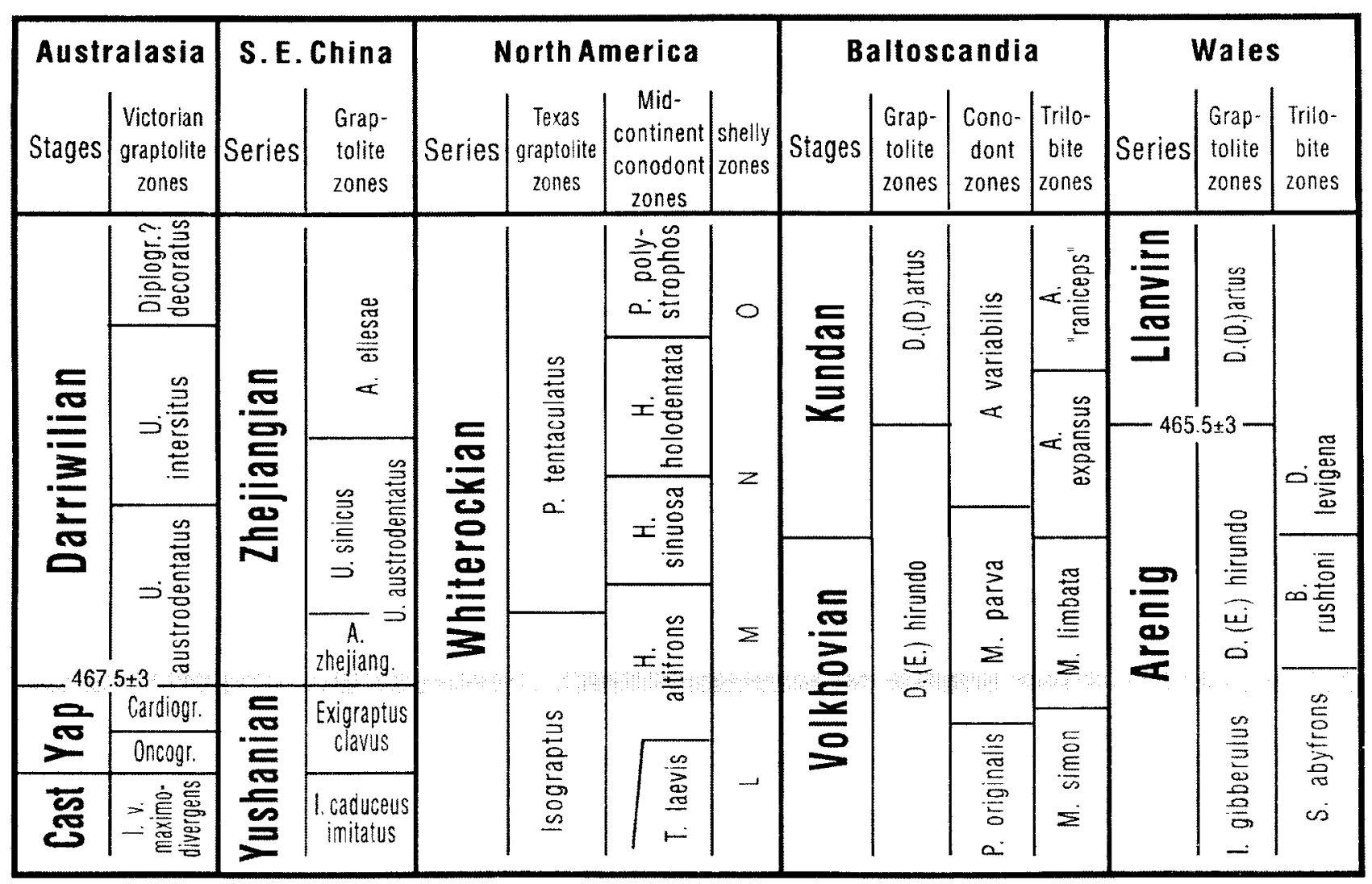

Figure 7 Correlation chart showing chronostratigraphic relations between the base of the recently ratified global Darriwilian Stage of the Middle Ordovician Series and several well-known regional series and stages based on data and interpretations cited in Mitchell and Chen (1995) and Mitchell and Maletz (1995), with radiometric ages interpolated based on data from Tucker et al. (1995) and Huff et al. (1997), and relative stage durations from Cooper (1992).

\section{Correlation of the base of the Darriwilian Stage}

The distinctive fauna of the $U$. austrodentatus Biozone has been reported from Australia. New Zealand. North America. Europe. South America, China. Mongolia, and Kazakhstan permitting confident correlation with these regions (Figure 7). A. zhejiangensis Subrone faunas oceur in the Marathon region. Texas, and similar launas are also present elsewhere along the western North American Cordillera (Mitchell and Chen Xu 1995). An (\% sinicus Subrone fauma has been recorded from Quebee and Newfoundland (Mitchell and Maletz 1995). Correlations with faunas from North America indicate that the base of the $U$. sinicus Subzone is nearly coincident with the base of the widely recognized Paraglossograptus tentaculatus Biozone. Similar relationships are present in the Argentine Precordillera (Ortega and others 1993: Albanesi and others, 1995; Ediel Brussa and C.E. Mitchell. unpublished data).

The oldest diplograptacean known from Wales is Undulograptus. cumbrensis from the Bergamia rushtoni Biozone (Figure 7). Its FAD is certainly within the U. sinicus Subzone (Mitchell and Malctz. 1995). The base of the U. austrodentatus Biozone. therefore, should lie below the oldest occurrence of diplograptaceans yet discovered in Wales, within the lower part of the Fennian Stage. The interval of the lower $U$. austrodentatus Biozone is represented in North Wales (as at Nant $y$ Gadwen) and in the Skiddaw Group of the Lake District, based on the presence there of $A$. zhejiangensis (reported as $P$. angel) in the upper Isograptus caduceus gibberulus Biwone (Fortey and others, 1990). The $U$. sinicus Subzone is presem in younger rocks of the Lake District, where it is equivalent to the Didymograptus hirundo Biozone as used by Jackson (1962) and in North Wales near Caernarfon and Bangor (Fortey and others. $1900)$.

In Sweden, A, thejiangensis occurs in the middle part of the $D$. hirundo Biosone together with Pseadisograptus manubriatus jants and Pseadophyllograptus cor. U. sinicas and $U$. cumbrensis occur in the upper 6 . hirundo biorone (Mitchell and Malet. 1995). The base of the L lanvirn most likely coincides with a level slightly above the base of the A.?' "llesce Biozone of southeast China. which is closely comparable to the Undulograptus intersitus Biozone (Darriwilian 2) in Australia and New Zealand. Conodont evidence from the JCY area indicates that the base of the A.? ellesce Biorone cor responds to a level near the base of the Amorphognathes rarieblis Biozone. which is in agreement with the conodont age of the rocks in the Arenig-L lanvirn boundary interval in the Baltic region.

As mentioned previously. conodont evidence from the JCY area indicates that the base of $U$. atrstrodentatus Biozone is in strata that probably correspond to either the upper part of the Baltoscandian Paroistodus originalis Biozone or lower part of the Microzarkodina parva Biozone. Comparison with the Yangtze Platform conodont succession favors the latter interpretation (Bergström and Wang. 1995). The conodont zonal assignment of rocks from both Sweden and Nevada that, based on their graptolite faunas, are correlatives of the lower U. atustrodentatus Biozone also lall within the M. parva Biozone. Strata of the A. ellesale Biozone in the JCY area (e.g., AEP 250) as well as rocks from just above the $U$. austrodentatus Biozone in Quebec and Sweden belong to the A. variablis Biozone (Bergstrom and Wang, 1995: Mitchell and Malet/, 1995). The A. variablis Biozone fauna at Huangnitang includes the distinctive (albeit newly recognized) conodont, Eoplacognathus crassus Chen and Zhang, which is also present in this same interval in the Yangtze platform region, as well as at localities in Sweden, Estonia, and Poland (see Zhang, 1997). E. crassus appears to be a short rang- 
ing species restricted to the lower, but not lowermost, part of the $A$. variabilis Biozone (i.e. the upper part of the A. variabilisMicrozarkodina flabellam Subzone). Based on these conodontgraptolite relations we are confident that the age of the base of the $U$. austrodentatus Biozone is consistent across both the Pacific and Atlantic provinces.

\section{References}

Alhanesi. G 1. Hünicken. M A. and Ortega. G. 1995. Review of Ordovician conodont-graptolite hiostratigraphy of the Argentine Precordillerit, in Cooper, J D, Droser, M L. and Finney, S C, eds., Ordovician Odyssey: Short Papers for the Seventh International Symposium on the Ordovician System: Pacific Section. Society for Sedimentary Geology (SFPM). Book 77, pp. 31- 35

Bergström. S M and Wang Zhi-hao, 1995, Global correlation of Castlemainian 10 Darriwilian conodont faunas and their relations to the graptolite zone succession. in Chen Xu, and Bergström. S M. eds., The base of the arsirodentatus Zone as a level for global subdivision of the Ordovician System: Palacoworld, no. 5. pp. 92-98.

Berry, W B N. 1968. British and North American Lower Ordovician correlation--reply: Bulletin of the Geological Society of Americal. v. 79. pp. $1265-1272$

Berry, W B N. 1995, Plate motions, oceanographic change and ecologic controls: influence on correlation of the base of the Llanvirn Series. Ordovician System: Newsletters in Stratigraphy. v. 32. pp. 45-55.

Chen Xu, and Bergstrom, S M, (eds). 1995. The base of the austrodentums Zone as a level for global subdivision of the Ordovician System: Palacoworld, no. 5. 177p.. 8 pls.

Chen Xu. Zhang Yuan-dong. and Mitchell. C E. 1995a. Castlemainian to Darriwilian (Late Yushanian to early Zhejiangian) graptolite faunas, in Chen Xu, and Bergström. S M. eds.. The base of the austrodcntatus Zone as a level for global subdivision of the Ordovician Systent: Palacoworld. no. 5. pp. $36-66$

Chen Xu. and Mitchell, C E. 1995. International correlation of the Undulegraptus austrodentatus 7one. in Chen Xu. and Bergström. S M. eds.. The base of the austrodentatus Zone as a level for global subdivision of the Ordovician System: Palacoworld. no. 5. pp. 75-85.

Chen Xu. Mitchell, C. E. Zhang Yuan-dong. Bergstrum, S M. Winston, D. Wang Zhi-hato. and Malety, J, 1995b. Craptolite species succession across the base of the Undulogiatus austrodentatus \%onc at Huangnitang. South-central China and its prospects for use as a global stage stratotype. in Cooper, J D. Droser. M L. and Finney, S C, eds.. Ordovician Odyssey: Short Papers for the Seventh International Symposium on the Ordovician System: Pacific Section. Socicty for Sedimentary Geology (SEPM). Book 77, pp. 157-162.

Cooper. R A, 1992. A relitive timescale for the Early Ordovician derived from depositional rates of graptolite shales. in Webby. B D. and Laurie J R, eds., Gilobal Perspectives on Ordovician Goology: Balkema, Rotterdam. pp. 3-21.

Cooper, R A. and Fortey, R A. 1982. The Ordovician graptolites of Spitsbergen: Bulletin of the British Museum (Natural History). Geology, v. 36. pp. $157-302$.

Cooper. R A, and Lindholm. C. 1990. A precise worldwide correlation of early Ordovician graptolite sequences: Geological Magazine, v. 127, pp. $497-525$

Elles. G. 1925. The characteristic assemblages of the graptolite zones of the British Isles: Gicological Magazine. v. 62. pp. 337-347.

Finncy. S C. and Ethington. R L, 1992. Whiterockian graptolites and conodont from the Vinini Formation, Nevada: biostratigraphic implications. in Webby, B D. and Laurie J R. eds.. Global Perspectives on Ordovician Geology: Balkema. Rotterdann. pp. 153-169.

Fortey. R A. Bassett. M G. Harper, D A T. Hughes, R A. Inghaun. J K. Molyneux. S G. Owen. A W. Owens. R M. Rushtem. A W A. and Sheldon. P R. 1991. Progress and problems in the selection of stratotypes for the bates of the series of the Ordovician System of the historical type area in the U.K. in Barnes, C. R and Williams. S H, eds.. Advances in Ordovi. cian Geology. Geological Survey of Canadia, Paper 90-9. pp. 5-25.

Fortey. R A. Beckly. A J. and Rushton. A W A. 1990. International correlation of the hase of the Llanvirn Series. Ordovician System; Newsletters in Stratigraphy. v. 22, pp. 119-1+2

Fortey. $R$ A, and Cooper. 1986. A phylogenetic classification of the graptoloids: Palateontology. v. 29. pp $6,31-6,54$.
Fortey, R A. Harper, D A T. Ingham, J K, Owen. A W and Rushton. A IV A. 1995, A revision of Ordovician series and stages from the historical type area: Geological Magarine. v. 132, pp. 15-30.

Fortey, R A. and Owens, R, M. 1987. The Arenig series in south Wales: Bulletin of the British Muscum Natural History (Geology). v. 41. pp. 69. 307.

Jackson, D F, 1962. Graptolite zones in the Skiddaw Group in Cumberland. England: Journal of Palcontology, v. 36. pp. 300-313.

Hall, TS, 1899 , Victorian graptolites: P. I1. The graptolites of the Latredicld beds: Procecdings of the Royal Society of Victoria. v. 11. pp. 104-178.

Harris. W J. 1916. The palieontological sequence of the Lower Ordovician rocks of the Castlemaine district, Part I: Proceedings of the Royal Society of Victorial, v. 29, pp. 50-74.

Harris, W J. 1935. The graptolite succession of Bendigo East, with suggeved zoning: Proceedings of the Royal Society of Victorial, v. 47, pp. 314.37.

Harris, W J, and Keble, R A. 1932. Victorian graptolite tones, with correlations and descriptions of species: Proceedings of the Royal Society of Victoria. $v .44 . \mathrm{pp} .25-48$.

Huff, W D and Bergstrom. S M, 1995. Castlemainian K-bentonite beds in the Ningkuo Formation of the Jiangshan County - the first lower Ordovician K-bentonites found in China, in Chen Xul, and Bergström. S M. eds.. The base of the austrodentatus 7 one as a level for global subdivision of the Ordovician System: Palaleoworld. no. 5. pp. $101-103$.

Huff, W D. Davis, D. Bereström, S M. Krekeler M P S. Kolata. D R. and Cir golani. C. 1997. A biostratigraphicall! well-constrained K-bentonite U$\mathrm{Pb}$ zircon age of the lowermost Darriwiljan Stage (Middle Ordovician) from the Argentine Precordillera: Episodes. v. 20. no. 1. pp. 29-33.

Maletz. J. 1992. The Arenig/Llanvirn boundary in the Quebec Appalachians: Newsletters in Stratigraphy, v. 26. pp. 49-64.

Mitchell. C E. 1992. Evolution of the Diplograptacea and the international correlation of the Arenig-L lanvirn boundary. in Webby. B D. and Laurie J R. eds.. Global Perspectives on Ordovician Geology: Balkema, Rotter dam, pp. $171-183$.

Mitchell, C E. 1994. Astogeny and rhabdosome architecture of graplolites of the Undulograptues austrodentatus species group. in Chen X. Erdtmann B D, and Ni Y N. eds.. Graptolite Research Today: Academia Sinica. pp. $49-60$.

Mitchell, C E. and Maletz. J, 1995. Proposal for adoption of the base of the Undulograputs castrodentontes Biozone as a global Ordovician stage and series boundary level: Lethaia, v. 28, pp. 317-331.

Ortega, G. Toro, B. and Brussa, E, 1993. Las zonals de graptolitos de la formación Gualcamayo (Arenigiano tardio - Llanvirniano temparano) en el Norte de la Precordillera (Provincias de La Rioja y San Juan). Argentina: Revista Española de Paleontologia, v. 8. pp. 207-219.

Paris, F. 1990, The Ordovician chitinozoan biozones of the Northern Giondwana Domain: Review of Paleobotany and Palynology. 8. 66. pp. $181-209$.

Paris, F. and Chen Xu. 1995. Early Ordovician chitinozoans from the Huangnitang section and nearby localities in the Jiangshan-Changshan-Yushan (JCY) area. In: Chen Xu, and S.M. Bergström eds. The base of the altstrodentatus Zone as a level for global subdivision of the Ordovician System, Palaeowortd. no.5. pp. 99-100.

Paris, F., and Chen Xu 1996. Contribution of the chitinozoans to the selection of a GSSP for the base of the Middle Ordovician in southern Chinat. 9th International Palynologic Congress. Houston. Texas. June 23-28, 1996 (Abstract).

Servais. T. Brocke. R, and Fatka, O. 1995. Variability in the Ordovician acritarch Dicrodiacrodium: Palacontology. v. 39, pp. 389-405.

Skevington. D, 1963, A correlation of Ordovician graptolite beating sequences: Geologiska Föreningens i Stockholm Förhandlingar. y 85. pp. 298-319.

Tucker. R D. and McKerrow. W S. 1995. Early Paleozoic chronolong: at review in light of new $\mathrm{U}-\mathrm{Pb}$ zircon age from Newfoundland and Britain: Canadian Journal of Earth Sciences, 1. 32. pp. 368-379.

VandenBerg. A H M. and Cooper, R A, 1992. The Ordovician graptelite sequence of Australasia: Alcheringa. 3. 16. pp. 33-85.

Vavedová, M. 1993. Acritarch assenblages in the Arenig Series of the Prague Basin. Crech Republic: Special Pappers in Palaeontology. 1.48 . pp. 125-139.

Webby, B D. 1994. Towards establishing globally applicable boundaries for the Ordovician System: Major international divisions and criteria for definitions: Ordovician Neus, v. 11 . pp. 0-15.

Webby. B D. 1997. Sone comments on Ordovician subdivisions and uage. Ordovician News. Y. 14. (in press).

Wang Zhi-hao, and Bereström. S M. 1995, Castlemainian (Late Yushamian) to Darriwilian (Zhejiangian) conodont faunas. in (chen Xu. and Bergström. S M. eds.. The hase of the austrodentatus Zone as a level for 
global subdivision of the Ordovician System: Palaeoworld, no. 5, pp. 86-91.

Williams, A, Strachan, I, Bassett, D A, Dean, W T, Ingham, J K, Wright, A D, and Whittington, H B, 1972, A correlation of the Ordovician rocks in the British Isles: Geological Society of London Special Report no. 3, 74p.

Xiao Chengxie and Chen Hongye, 1990, Some graptolite faunas of the Lower and Middle Ordovician from Gucheng area, Yushan: Geology of Jiangxi v. 4, no. 2, 244 p. (in Chinese with English summary).

Zhang, Jian-hua, 1997. The Lower Ordovician conodont Eoplacognathus crassus Chen and Zhang, 1993; GFF, v. 119, pp. 61-65.

Zhang Yuan-dong, 1995. Graptolite composite standard sequence (GCSS), in Chen $\mathrm{Xu}$, and Bergström, S M, eds., The base of the austrodentatus Zone as a level for global subdivision of the Ordovician System: Palaeoworld, no. 5, pp. 67-74.

Charles E. Mitchell is an associate professor and Assistant Chair in the Department of Geology at the State University of New York at Buffalo (cem@acsu.buffalo.edu).Research interests include graptolite evolution and biostratigraphy, as well as application of stratigraphy to understanding basin history and tectonics. He is a Titular member of the ICS Subcommission on Ordovician Stratigraphy (since 1996), and Secretary and newsletter editor for the Graptolite Working Group of the International Palaeontological Association.

Chen Xu, Born in 1936, Graduated from the Beijing College of Geology in 1959, employed by the Nanjing Institute of Geology and Palaeontology. Academia Sinica from 1959 to present. Research professor from 1989, Vice-Chairman of the Ordovician Subcommission from 1991. Research field: Ordovician and Silurian stratigraphy and graptolites.
M. Bergström is professor of Geological Sciences at Ohio State University, USA where he has been teaching since 1968 after having received his graduate training at Lund University, Sweden. He has been a voting member of the Subcommission on Ordovician Stratigraphy since 1974 and served as subcommission secretary in 19761982. His principal research interest is global Ordovician geology, especially aspects of the evolution of the lapetus, the significance of Lower Paleozoic K-bentonites, and conodonts and graptolite morphology and biostratigraphy.

Zhang Yuan-dong, Born in 1967, Graduated from the Changcun College of Geology in 1987, Received Ph.D. from the Nanjing Institute of Geology and Palaeontology, Academia Sinica in 1993 and employed by the Institute. Associate professor of the Institute from 1994. Working on Ordovician and Silurian biostratigraphy and graptolites.

Wang Zhi-hao, Born in 1941, Graduated from the Nanjing University in 1965, employed by the Nanjing Institute of Geology and Palaeontology, Academia Sinica from 1965 to present. Research professor from 1996. Working on Ordovician stratigraphy and conodonts.

Barry D Webby is a senior research geologist at the Macquarie University Centre for Ecostratigraphy and Palaeobiology, Australia, with active interests in a number of aspects of Ordovician geology and the palaeontology of calcified sponges. He was Chairman of the ICS Subcommission on Ordovician Stratigraphy from 1989 to 1996, and is now one of the leaders of IGCP project 410 focusing on the great Ordovician biodiversification event.

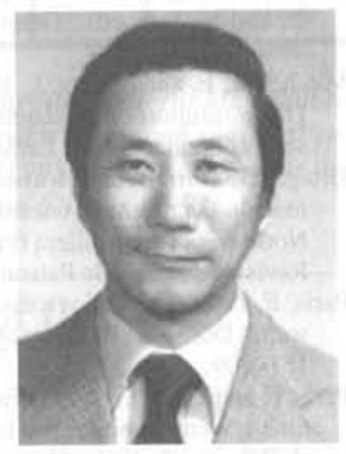

Stanley C. Finney is Professor and Chair in the Department of Geological Sciences at California State University, Long Beach. His research interests include graptolite systematics and biostratig. raphy, the Late Ordovician extinction, and stratigraphy and paleon. tology of Ordovician rocks of the Great Basin. Finney is Chair o, the ICS Subcommission on Ordovician Stratigraphy. 